\title{
Youth Migration Aspirations in Georgia and Moldova
}

\author{
Christina Diane Bastianon ${ }^{\ddagger}$
}

\begin{abstract}
This study investigates in what ways individual and household capabilities and their general life aspirations affect migration aspirations in particular, among Georgian and Moldovan youth. The utilized sample was extracted from nationally representative surveys and considers youth aged 11 to $19(N=3,583)$. Multi-level, step-wise probit models are used to predict youth migration aspirations. Among the findings are that individual capabilities, aspirations, and household capabilities significantly impact youth migration aspirations, while household aspirations are statistically insignificant. The results further emulate the importance of residential satisfaction, the effects of gendered social norms and inequalities on youth migration aspirations.
\end{abstract}

Keywords: youth; migration; capabilities; aspirations; Georgia; Moldova.

\section{Introduction}

Understanding why people migrate and who is migrating are key questions addressing individual and environmental factors that influence the migration process. A prerequisite for voluntary migration is to have migration aspirations (Carling, 2002; Carling \& Schewel, 2017; Czaika \& Vothknecht, 2012; de Haas, 2014). Terminology relating to migrant decision-making is inconsistent; some scholars use concepts of aspirations, desires, and intentions synonymously while others distinguish between these terms. Robert Gardner (1981: 65) explicitly states that "the desire to move is not equal to intentions or the decision to move since perceived constraints intervene", similarly, "the intention or decision to move does not equate to actual migration as real constraints intervene". This study uses 'aspirations' to capture desires toward the future. Bernard and Seyoum Taffesse (2014) express that aspirations span multiple dimensions of one's life and can be intertwined. For instance, “... [One] may have aspirations for health aspirations, wealth or income aspirations, educational aspirations, social status aspirations... [one] may also generally aspire to a better life, to which each of these dimensions contribute at various degrees" (Bernard \& Seyoum Taffesse, 2014: 200). Thus showing the intricacy of how specific aspirations may influence other life aspirations. Although aspirations are a complex concept, migration research has relied on migration aspirations as a guiding indicator of migration behavior.

\footnotetext{
¥ Christina Diane Bastianon, Medical Psychology and Medical Sociology, Department of Psychosomatic Medicine and Psychotherapy, University Medical Center of the Johannes Gutenberg University of Mainz, Mainz, Germany. E-mail: cbastian@unimainz.de.

Acknowledgements: This research was conducted as part of my master thesis at Maastricht University, Graduate School of Governance, under the supervision of Dr. Michaella Vanore. I would like to convey my gratitude for her guidance, wisdom, and academic humor throughout the thesis process. I am beyond grateful for Stefan Bührer (M.Sc.) and Jan Yaqub (M.Sc.) for their support throughout the editing process. Thank you to the Migration Letters journal reviewers for feedback and to the wonderful organizers of the MOVE Conference 2018 .
} 


\section{Youth Migration Aspirations in Georgia and Moldova}

DaVanzo (1981: 90) stresses the relevance of understanding migration motivations and decision-making mechanisms for policy makers, as they are predictors of future migration patterns and thus potential shifts in political power and economic activity. For instance, youth emigration from a rural community may leave local economies stagnant and political representation may shift based on changing demographics. Bjarnason (2014) ascertains that youth migration intentions predict population changes in Icelandic communities, thus changing the age composition of these communities over a 20 year period. Scholars have shown that a plethora of economic, social, and psychological factors influence migration decision-making behavior, yet very few have focused on youth. The research question of this study is: how are youth migration aspirations influenced by individual and household capabilities and general life aspirations in Georgia and Moldova?

\section{Georgia and Moldova}

Georgia and Moldova share a similar history as post-Soviet states, exhibit comparable geopolitical relations to the EU and Russia and youth face similar challenges thereby lending themselves for a case study. After the fall of the Soviet Union both countries struggled in their transition towards independence, observed in high unemployment, unstable economic markets and a quarter of either population emigrating (Danzer \& Dietz, 2014; Hofmann \& Buckley, 2012; Vanore, 2015; Vanore \& Siegel, 2015). In the last twenty years, political relations with Russia have deteriorated resulting in sanctions and visa requirements towards Georgia and Moldova (Danzer \& Dietz, 2014; Hofmann \& Buckley, 2012). In 2004, the European Commission implemented the European Neighborhood Policy (ENP) ${ }^{1}$ framework in order to strengthen relations with the EU's eastern and southern neighbors thus easing access to its labor and economic markets (Danzer \& Dietz, 2014).

Youth unemployment (ages 15-24) in Georgia and Moldova is more than twice their national averages. In 2016, Georgia's youth unemployment rate was $30.5 \%$ versus $11.8 \%$, the national average (World Bank, 2017b, 2017a). In the same year Moldova's youth unemployment rate was $11.2 \%$ with a national average of $4.2 \%$ (World Bank, 2017a, 2017b). Additionally, a mismatch between education and job opportunities providing competitive wages is observable; thus leading to unstable employment conditions, over-qualified youth, job insecurity and underemployment (National Council of Youth Organizations of Georgia, 2009; Vanhee, Hämäläinen, Brandtner, Titarenko, \& Williamson, 2009). The aforementioned aspects demonstrate challenges Georgia and Moldova face, which, in theoretical terms, might lead youth to move abroad in search for work, higher wages, and better life opportunities.

Furthermore the Georgian and Moldovan governments expressed concerns of aging populations, 'brain-drain' and 'brain-waste' as a result of emigration (Badurashvili \& Nadareishvili, 2012; Vladicescu \& Vremis, 2012). Detailed data for Georgia and Moldova is available and both pose as new migrant source countries for EU member states (Badurashvili \& Nadareishvili, 2012; Vladicescu \& Vremis, 2012). This study is relevant as results have theoretical implications for youth migration decision-making along with inform government officials of factors prompting youth migration aspirations in Georgia and Moldova. The paper structure is as follows: the next section

\footnotetext{
${ }^{1}$ European Neighborhood Policy framework works to integrate the participating countries' democracy, rule of law, respect for human rights, and social cohesion to EU standards. Partner countries include: Algeria, Armenia, Azerbaijan, Belarus, Egypt, Georgia, Israel, Jordan, Lebanon, Libya, Republic of Moldova, Morocco, Syria, Palestine, Tunisia, Ukraine. As a more detailed result of the ENP, in 2009, the Eastern Partnership (EaP) pushed forward political association and economic integration of six of the ENP countries, including Georgia and Moldova, through Association Agreements and Deep and Comprehensive Free Trade Areas (AA/DCFTAs). Visa liberalization for Moldovans in 2014 and for Georgians in 2017 are key outcome from these agreements, allowing citizens easier access to the EU member states (see EEAS, 2016).
} 
briefly addresses previous literature. The data and statistical processes and sample overview is explained; followed by the results. The paper ends with a discussion of relevance to the broader migration field.

\section{Theoretical Background}

The theoretical backdrop and guidance for variable selection is based on De Jong's (2000) general model of migration decision-making and Carling's (2002; Carling \& Schewel, 2017) aspiration/ability model. The aspiration/ability model describes migration as a function of the aspiration to migrate - based on the emigration environment and individual characteristics - as well as the ability to migrate - based on immigration interface and again individual characteristics. Emigration environment refers to the social, economic, and political context from which people are emigrating, while the immigration interface incorporates all the costs and risks associated with the various modes of migration (e.g. legal labor migration, family reunification, political asylum, visa overstaying, and illegal entry) (Carling, 2002). While De Jong (2000) incorporates seven concepts that enable migration decision-making: expectations/values, perceived family migration norms, gender roles, residential satisfaction, migrant networks, and direct behavioral constraints and facilitators.

Both models outline the importance of a multilevel analysis including individual (micro), household or community (meso) and national (macro) levels. They further incorporate that the decision to migrate is complex and not limited to just economic motivators, but include social, cultural, and political aspects. Cohen and Sirkeci (2011; Sirkeci \& Cohen, 2016) compliment this by modeling how a 'culture of migration' in combination with conflict - ranging from subtle tensions to violent disputes- influence a household and its members to migrate internally and internationally. Economic, social, and gender inequalities plague the migration process; when inequalities precede migration decision-making, these inequalities will continue to influence migration opportunities and aspirations by maintaining barriers of migration (Carling, 2002; Carling \& Schewel, 2017). Furthermore, these inequalities will create asymmetric migration outcomes (Cohen \& Sirkeci, 2011), where financial recourses may influence one's final destination and gender differences may shape bargaining power and familial roles leading to alternative migration paths (Cohen, Rodriguez, \& Fox, 2008). It is with these models one can see how inequalities in individual and family resources, as well as, in the cultural and social contexts may influence the migration process.

\section{Migration Aspirations}

Youth are often viewed as being dependent on their parents or households and therefore their decision-making becomes distorted (Heckert, 2015). Scholars point to the ongoing negotiations between parents and children throughout their transition to adulthood and ultimately towards more independence (Iversen, 2002; Lauby \& Stark, 1988; Punch, 2002; Whitehead, Hashim, \& Iversen, 2007). Migration is one way by which youth establish independence and autonomous decisionmaking (Carling \& Talleraas, 2016; Punch, 2002), however Whitehead et al. (2007) recognize that a youth's decision to migrate is generally negotiated between them and their parents. In other cases, household conflicts might provoke an independent decision to migrate among youth. Such conflicts were the chief reason for the young men (13-14 years old), whom Iversen (2002) studied, to become more autonomous through their decisions to migrate in search for better job prospects. Cohen and Sirkeci (2011) model migration as a response to various forms of conflict, including intra-household conflict and between individuals within a community. Parenting styles and the parent-child 


\section{Youth Migration Aspirations in Georgia and Moldova}

relationship heavily influence youth. Kao (2004) shows how parenting styles across various ethnic groups influences the youth's educational outcome and that parental aspirations impact youth's academic success. However, a young person's decision to migrate, thereby leave their home country, family, and friends, also heavily depends on individual characteristics.

Personality traits such as self-efficacy (Bandura, 1994) along with locus of control (Rotter, 1966) directly relate to aspiration formation and subsequent behavior (Bernard \& Seyoum Taffesse, 2014; Carling, 2002; Czaika \& Vothknecht, 2014; de Haas, 2014; De Jong \& Fawcett, 1981; De Jong, Root, Gardner, Fawcett, \& Abad, 1986; van Dalen \& Henkens, 2008). Czaika and Vothknecht (2014) discover about 30 percent of a migration aspirations gap was explained by an unobservable characteristic to which they link personality traits to migration. Thus, youth's personality traits guide aspiration development and decision-making.

Perceptions of residential and life satisfaction shape migration aspirations, intentions and migration behavior. Discontent or shame experienced in home countries' economic and political environments is cited as a common push factor encouraging migration abroad or prolonging return migration (De Jong, 2000; Kahanec \& Fabo, 2013; Pinger, 2010). De Jong et al. (1986) asserts that value-expectancy from perceptions of place utility is only significant for migration intentions but not for behavior. In contrast, Van Dalen and Henkens (2008) demonstrate that discontent with the public domain, including public institutions along with goods and services provided by the government, is a significant trigger affecting migration intentions and behavior. Furthermore, their results show that negative perceptions of private living conditions (home, work and income) signify positive migration intentions. Similarly, Gubhaju and De Jong (2009) find that people with higher life satisfaction are less likely to have migration intentions.

Individual or household economic constraints and/or expectations can similarly influence migration aspirations. Individuals lacking capital cannot afford to migrate but likewise financial insecurity can reduce one's 'capacity to aspire' (Carling, 2002; Carling \& Schewel, 2017; Czaika \& Vothknecht, 2014; de Haas, 2014; Horváth, 2008). Lower income and household vulnerability have been shown to reduce intentions to migrate (Czaika \& Vothknecht, 2014; Loschmann \& Siegel, 2013). New Economics of Labor Migration (NELM) states that households will diversify income sources based on risk in various markets (Massey et al., 2009; Stark \& Bloom, 1985). This observation justifies the phenomena of family members migrating and sending remittances home. When the decision to migrate is made at the household level, the chosen individual may feel pressure from the family or community to send remittances or meet certain expectations. Pressure exerted from the family has been shown to affect migration intentions significantly (De Jong, 2000; De Jong et al., 1986). On the contrary, Heckert (2015) shows that youth who migrate abroad for work or education often heavily rely on family support and thus are incapable of sending remittances. Furthermore, families view migration as an investment in human capital hoping it will pay off once youth enter the labor market. Thus economic stability and expectations about financial support should be considered when examining migration aspirations.

\section{Methodology}

Data. This study uses secondary data derived from the project "The Effects of Migration on Children and the Elderly Left Behind in Moldova and Georgia" (CELB-MD/GE) jointly completed by Maastricht Graduate School of Governance (MGSoG), Kiel Institute for the World Economy (IfW) and the International Centre for Social Research and Policy Analysis (ICSRPA) and funded 
by the European Commission ${ }^{2}$. Data was collected from December 2010 through June 2013 from households that included at least one member under 18 or elderly over 60 . The household head, caregiver, and youth were independently interviewed for the various sections of the survey. The semi-autonomous region of Transnistria in Moldova and the de facto independent regions of Abkhazia and South Ossetia in Georgia were not included in the survey framework.

Sample. The Georgian and Moldovan youth sample includes 3,583 young people (12.6\% of total sample) between the ages of 11 and 19 , of which males represent $52.3 \%$ of total youth and females $47.7 \%$. Of the larger youth sample, 2,058 responded to the question asking about migration aspirations. Table 1 outlines youth migration aspirations by gender, country and residence. Less than half of the youth sample (37.5\%) has aspirations to live or work abroad. Of the males, $36.8 \%$ aspire to migrate.

Table 1. Migration Aspirations (\%)

\begin{tabular}{llll}
\hline & & Yes & No \\
\hline Total Youth & $(\mathrm{n}=2,058)$ & 37.5 & 62.5 \\
Gender & Male $(\mathrm{n}=1,033)$ & 36.8 & 63.2 \\
& Female $(\mathrm{n}=1,025)$ & 38.2 & 61.8 \\
Country & Georgia $(\mathrm{n}=1,184)$ & 30.6 & 69.5 \\
& Moldova $(\mathrm{n}=874)$ & 42.6 & 57.4 \\
Residence & Urban $(\mathrm{n}=642)$ & 35.7 & 64.3 \\
& Rural $(\mathrm{n}=1,416)$ & 38.4 & 61.7 \\
\hline
\end{tabular}

Statistical Procedure. The two country data files were cleaned, merged, and checked for systematic biases. Household variables were computed (Appendix A). The statistical tool used to analyze the data was Stata version 13.1. Based on the nature of the binary dependent variable, binary choice regressions were deemed the most appropriate method for analysis (Stock \& Watson, 2012). Four step-wise probit models reflecting individual and household capabilities and aspirations were used in predicting youth migration aspirations (Table 2). Two additional models tested the variation of gender outcomes (Appendix B). Table 2 reports the average marginal effects of individual and household capabilities and general life aspirations on youth migration aspirations specifically. The coefficients should be interpreted as a percentage point change in the probability of having migration aspirations.

Variables and Operationalization. The dependent variable, migration aspirations, reflects the question directly posed to youth "Would you like to live or work in a different country". 1 indicates positive migration aspirations while 0 reveals no migration aspirations. Variables were chosen and grouped into six categories (individual and household capabilities, general life aspirations, and characteristics) which are based on the work of Carling (2002) and De Jong (2000). Appendix A provides an overview of the variables, questions, possible responses, means and standard deviation.

${ }^{2}$ For more detailed information about data collection and the CELB-MD/GE project please see methods section of: Vanore, M. (2015). Family-Member Migration and the Psychosocial Health Outcomes of Children in Moldova and Georgia. Maastricht University, Maastricht. 


\section{Youth Migration Aspirations in Georgia and Moldova}

\section{Results}

This section will first present results for the full model (4) in line with the developed categories mentioned above. Gender sub-sample results will follow demonstrating the stark differences between males and females.

General results. As evident from the average marginal effects presented in Table 2, individual capabilities, youth life aspirations and household capabilities are significant, thus predict youth migration aspirations. General household aspirations are insignificant. Overall, individual and household capabilities, life aspirations and characteristic variables keep consistent significance levels, magnitudes and directions across the four probit models.

In regard to individual capabilities, this study shows that being a member of a group or club in the local area or at school (network) reveals a small positive relationship to youth migration aspirations. This was expected as the presence and location of networks are generally linked with establishing and maintaining migration trends (Haug, 2008; Massey et al., 2009). One's decisionmaking autonomy showed an expected negative, albeit it small, effect; demonstrating that youth who do not make decisions about daily life are less likely to have migration aspirations. Considering that more than $68 \%$ of the youth (Appendix A) declared they make only some or no decisions about daily life, this affects the majority of youth in the sample. Individual educational aspirations and perceptions of control in one's life showed significant effects; thus supporting the relevance of individual life aspirations in predicting specific youth migration aspirations. Educational aspirations were only significant for youth who wish to obtain a doctoral degree, increasing the probability of having migration aspirations by 27 percentage points. No other levels of educational aspirations were significant. By including individual characteristics we see that youth's pride in the country outweighs all other variables' impact on youth migration aspirations. This demonstrates that residential satisfaction is the strongest predicting factor of youth migration aspirations. Youth who are not at all proud of their country are 52 percentage points more likely to have migration aspirations compared to their proud peers.

In regard to household capabilities, the full model (4) shows that youth in households that worry the least are more likely to have migration aspirations by 24 percentage points as compared to youth in households that worry daily, further supporting the notion that those who migrate do not tend to belong to the poorest share of the population (de Haas, 2014). Household migrant network (migrant count) was surprisingly insignificant, thus contradicting the established thought that migrant networks encourage future migration aspirations by reducing the costs of migrating (de Haas, 2014; Haug, 2008; Massey, 1990). While the inclusion of household aspirations is supported by the understanding that youth are still heavily influenced by household members, household life aspirations were not significant in predicting youth migration aspirations. Household characteristics further explained variation in youth migration aspirations. As household life satisfaction, living conditions, pride in the country, all positively affect youth migration aspirations. Similar to the effect of youth's pride in the country, household's pride in the country shows a relatively large positive effect (24 percentage point change) on youth migration aspirations.

Youth's pride in the country, youth's educational aspirations for a doctoral degree, household's pride in the country, and household level of financial worry are the most noteworthy predictors of youth migration aspirations in the current sample of Georgian and Moldovan youth. However, while these factors have such relatively large effects on youth migration aspirations; they pertain to a minority of the sample (Appendix A). 
Table 2. Step-Wise Probit Models for Youth Migration Aspirations

\begin{tabular}{|c|c|c|c|c|}
\hline & $\begin{array}{c}\text { (1) } \\
\text { Individual } \\
\text { Capabilities }\end{array}$ & $\begin{array}{c}(2) \\
\text { Individual } \\
\text { Capabilities \& } \\
\text { Aspirations }\end{array}$ & $\begin{array}{c}(3) \\
\text { Individual } \\
\text { Capabilities \& } \\
\text { Aspirations \& } \\
\text { Household } \\
\text { Capabilities }\end{array}$ & $\begin{array}{c}(4) \\
\text { Individual \& } \\
\text { Household } \\
\text { Capabilities \& } \\
\text { Aspirations }\end{array}$ \\
\hline \multicolumn{5}{|c|}{ Individual Characteristics } \\
\hline Age & $0.02 * *(0.00)$ & $0.02 * *(0.00)$ & $0.02 * * *(0.01)$ & $0.02 * * *(0.01)$ \\
\hline Male & $-0.02(0.02)$ & $-0.01(0.02)$ & $-0.01(0.02)$ & $-0.01(0.02)$ \\
\hline $\begin{array}{l}\text { Enrollment } \\
\text { (ref. not enrolled) }\end{array}$ & $0.02(0.03)$ & $0.02(0.03)$ & $0.02(0.03)$ & $0.02(0.03)$ \\
\hline \multicolumn{5}{|c|}{ Youth's Pride in the Country (ref. Very Proud) } \\
\hline Proud & $0.17 * * *(0.03)$ & $0.19 * * *(0.03)$ & $0.15 * * *(0.03)$ & $0.14 * * *(0.03)$ \\
\hline Not Very Proud & $0.23 * * *(0.05)$ & $0.23 * * *(0.05)$ & $0.17 * * *(0.05)$ & $0.17 * * *(0.05)$ \\
\hline Not at all Proud & $0.52 * * *(0.17)$ & $0.52 * * *(0.16)$ & $0.50 * * *(0.16)$ & $0.52 * * *(0.14)$ \\
\hline Not Georgian/Moldovan & $0.02(0.12)$ & $0.02(0.11)$ & $-0.13(0.13)$ & $-0.12(0.13)$ \\
\hline \multicolumn{5}{|c|}{ Ethnicity (ref. Georgian/Moldovan) } \\
\hline Russian \& CIS & $0.01(0.07)$ & $0.01(0.07)$ & $-0.03(0.07)$ & $-0.03(0.07)$ \\
\hline Other & $-0.10 * *(0.04)$ & $-0.09 * *(0.04)$ & $-0.09 * *(0.04)$ & $-0.10 * *(0.04)$ \\
\hline \multicolumn{5}{|c|}{ Individual Capabilities } \\
\hline Network ${ }^{a}$ & $0.09^{* * *}(0.03)$ & $0.08 * *(0.03)$ & $0.08 * *(0.03)$ & $0.08 * *(0.03)$ \\
\hline \multicolumn{5}{|c|}{ Dependency in Decision-Making (ref. Not True) } \\
\hline Somewhat True & $-0.12 * * *(0.03)$ & $-0.12 * * *(0.03)$ & $-0.11 * * *(0.03)$ & $-0.11 * * *(0.03)$ \\
\hline Certainly True & $-0.07 * *(0.03)$ & $-0.06 *(0.03)$ & $-0.06 *(0.03)$ & $-0.06 *(0.03)$ \\
\hline Education Expectation & $0.00(0.00)$ & $0.00(0.00)$ & $0.00(0.00)$ & $0.00(0.00)$ \\
\hline
\end{tabular}

Education Aspirations (ref. Lower Secondary)

Upper Secondary
Post-Secondary
Bachelor
Master
Doctorate

$\begin{array}{ccc}0.02(0.10) & 0.03(0.09) & 0.02(0.10) \\ 0.06(0.09) & 0.07(0.08) & 0.06(0.09) \\ 0.04(0.08) & 0.06(0.08) & 0.04(0.09) \\ 0.03(0.09) & 0.04(0.08) & 0.02(0.10) \\ 0.26^{* * *}(0.10) & 0.29 * * *(0.09) & 0.27^{* *}(0.11) \\ -0.11^{* * *(0.03)} & -0.12^{* * *}(0.03) & -0.11^{* * *}(0.03) \\ 0.05(0.03) & 0.05 *(0.030) & 0.05(0.03)\end{array}$

Responsibility vs Destiny

Hard Work vs Luck

Household Characteristics

Country (ref. Georgia)

Urban (ref. Rural)

HH Size

HH Life Satisfaction

HH Living Condition

HH Pride in the Country (ref. Very Proud)

Proud

$-0.04(0.04)$

$-0.04(0.04)$

$0.01(0.03)$

$0.01(0.03)$

$-0.01(0.00)$

$-0.00(0.00)$

$0.01 * *(0.00)$

$0.01 *(0.00)$

$0.03 *(0.01)$

$0.03 *(0.01)$

Not Very Proud

$0.08 * *(0.03) \quad 0.08 * *(0.03)$

Not at all Proud

$0.15 * * *(0.04) \quad 0.15 * * *(0.04)$

$0.25 * * *(0.09)$

$0.24 * * *(0.09)$

Not Georgian/Moldovan

$0.25 *(0.14)$

$0.24 *(0.14)$

HH Education Level

$-0.00(0.01)$

$-0.00(0.01)$ 


\begin{tabular}{|c|c|c|c|c|}
\hline \multicolumn{3}{|c|}{$\begin{array}{l}\text { Dependency Ratio } \\
\text { Financial Worry (ref. Every Dav) }\end{array}$} & $0.00(0.00)$ & $0.00(0.00)$ \\
\hline \multicolumn{3}{|c|}{3 Times a Week } & $0.00(0.03)$ & $0.00(0.03)$ \\
\hline \multicolumn{3}{|c|}{ Once a Week } & $0.01(0.04)$ & $0.01(0.04)$ \\
\hline \multicolumn{3}{|c|}{ Once a Month } & $-0.01(0.04)$ & $-0.01(0.04)$ \\
\hline \multicolumn{3}{|c|}{ Less often or Never } & $0.24 * * *(0.07)$ & $0.24 * * *(0.07)$ \\
\hline \multicolumn{3}{|c|}{ HH Migrant Count } & $0.02(0.01)$ & $0.02(0.01)$ \\
\hline \multicolumn{5}{|c|}{ Household Aspirations } \\
\hline \multicolumn{5}{|c|}{$\begin{array}{ll}\text { HH Education Aspirations for Youth } & -0.00(0.01)\end{array}$} \\
\hline \multicolumn{3}{|c|}{ Parent encourages independent thinking } & & $0.04(0.06)$ \\
\hline \multicolumn{3}{|c|}{ Parent encourages hard work } & & $0.12(0.08)$ \\
\hline \multicolumn{3}{|c|}{ Expect Financial Support from Youth } & & $0.12(0.08)$ \\
\hline Pseudo R-Squared & 0.062 & 0.079 & 0.099 & 0.103 \\
\hline Observations & 1,319 & 1,319 & 1,319 & 1,319 \\
\hline
\end{tabular}

Gender-specific results. This section outlines key findings from gender sub-sample regressions (Appendix B). In regard to individual capabilities and youth life aspirations, there are stark differences in males and females. Being a part of a network is only significant for males. Whereas females are more influenced by not making decisions about daily life and their loci of control; indicating that females are more influenced by their ability and perceptions of decision-making and control over one's life. Educational aspirations for a doctoral degree are only relevant for males. This is somewhat surprising considering Heckert (2015) shows that young females are more likely to migrate for education compared to young males. There were no major gender deviations across individual characteristics.

As for household factors, household aspirations remained insignificant for both male and female models. However, there are clear gender divisions among household capabilities and characteristics in predicting youth migration aspirations. Females are, to a small extent, affected exclusively by household life satisfaction, living conditions, household's level of education and household financial worry, explicitly showing how predominant the household environment and opinions are in shaping young female migration aspirations. This is in contrast to males, where only two household factors influence young male migration aspirations - household pride in the country and household financial worry. Financial worry exhibits intriguing results, both males and females, in very different ways, are significantly impacted by household financial worries. Females are influenced by both high and low levels of financial worry (Appendix B), where females in households that worry the least are 43 percentage points more likely to have migration aspirations compared to females in households that worry every day. Amongst households that worry 3 times a week (compared to every day), males have a negative relationship to migration aspirations, while females have a positive relationship. This finding will be further discussed in the following section.

\section{Discussion}

This study investigated how youth migration aspirations are influenced by individual and household capabilities and life aspirations in Georgia and Moldova. Key findings include: (1) individual capabilities, youth life aspirations and household capabilities are significant in predicting 
youth migration aspirations, while general household aspirations are insignificant; (2) differences exist amid predictors of male and female migration aspirations.

A strength of this study, is its multi-level approach using micro and meso-factors in samples from Georgia and Moldova. Based on this foundation, individual capabilities, youth life aspirations and household capabilities showed significant effects on youth migration aspirations. Variables approximating social networks, financial stability, as well as residential and life satisfaction showed expected results and are comparable to previous studies that look at both youth (Bjarnason, 2014; Carling, 2002; Heckert, 2015; Horváth, 2008; Punch, 2002) and adult (Czaika \& Vothknecht, 2014; De Jong et al., 1986; Haug, 2008; van Dalen \& Henkens, 2008) samples; indicating that youth may have similar determinants of migration aspirations as adults. Heckert (2015) argued that there are distinct migration motives between youth and adults, which contradict current findings. Out of all variables included, model (4) shows individual and household pride in the country as two of the most prompting factors predicting youth migration aspirations. Although a very small portion of the total sample declared very little or no pride in the country, it has a relatively large effect when applicable. More important is the idea that poor residential and life satisfaction inspire youth migration aspirations. The combined effect of country pride and household views on life and living conditions fundamentally motivate youth and inspire migration for a better life. Perceptions of life circumstances are evaluated in relative terms and may define whether or not to migrate (de Haas, 2014). This evaluation is shaped by individual and household factors and is even more relevant when considering female populations as described below.

Although youth may still be heavily influenced by the opinions of household members, household aspirations, in this study, proved to be insignificant in predicting youth migration aspirations. This finding offers theoretical and methodological implications: (1) households are not one homogenous unit and (2) how aspirations are measured. From a theoretical standpoint, household aspirations are quite complex given that there are multiple family members within a single household. Iversen (2003) argues similar points when capturing intra-household inequalities. While family members (parents, caretakers and siblings) may have similar views regarding youth and their futures, there is no single bond within a household, thus each family member maintains a distinct relationship with the family's youth. Discussions of intra-household relations, conflict and bargaining power commonly enter migration research by viewing the decision to migrate as a household decision or strategy. The migration decision-making process may be affected by a 'black box' issue where conflict and bargaining within a household can alter an individual's decision (Gubhaju \& De Jong, 2009) but also influence one's destination and migration outcomes (Cohen \& Sirkeci, 2011; Sirkeci \& Cohen, 2016).

The second possibility for this finding is how aspirations were measured as single items. Considering that migration is generally viewed as a way to improve one's life; one option is to measure aspirations for a better life as an index (Bernard \& Seyoum Taffesse, 2014) capturing various life aspects including migration, education, wealth and health aspirations. Thus, researchers may reduce potential mediating effects among individual and household levels and across life aspirations. Trying to approximate household aspirations without understanding or capturing intrahousehold relationships leaves room for errors. Further studies must account for these intrahousehold relationships and explore methods of operationalizing individual and household aspirations. As Bernard et al. (2014) argue, aspirations are encompassed in multiple and potentially interrelated aspects of life and how they are measured may influence research outcomes. Therefore, the development of new appropriate measurement tools should be encouraged. 


\section{Youth Migration Aspirations in Georgia and Moldova}

Special emphasis on gender divisions emulate previous studies finding household opinions are most relevant in distinguishing male and female migration aspirations and behavior (Cohen et al., 2008; De Jong, 2000; Gubhaju \& De Jong, 2009; Lauby \& Stark, 1988). Females with less decisionmaking autonomy were less likely to have migration aspirations. While this might be affected by how young the sample was (11-19 years), this finding supports the notion that control and bargaining power within a household are altered by gendered social norms (Gubhaju \& De Jong, 2009; Lauby \& Stark, 1988). Given that females are significantly influenced by household life satisfaction, living conditions, and household education, this aligns with the assumption that, in certain circumstances, societal norms expect females to be responsible for service to their families and therefore remain dependent on the family (Cohen et al., 2008; De Jong, 2000; Lauby \& Stark, 1988; Whitehead et al., 2007). A discrepancy between societal and familial norms has often been mentioned as part of female migration decision-making; where family needs and social norms clash, leaving potential migrants in moral and even safety predicaments. Cohen et al. (2008) emphasize the contradictory pressures from immediate family members against communal social norms that placed women from Oaxaca, Mexico in precarious positions between the family's financial need and maintaining family honor, which is in complete contrast to men who decide to migrate. Similarly, in the Georgian context, Hofmann and Buckley (2012) investigated gendered social norms of women migrating from Georgia finding that, while migrating was seen as a necessary economic step, women still had to justify migrating to avoid being labeled an 'improper' woman. Therefore, a negative social perception of women who emigrate may further pressure younger females to withhold their own aspirations to emigrate. Males may rather feel a different responsibility to financially provide for the family; as this study shows, when households have unstable financial situations, males are less likely to have migration aspirations. This burden is discussed by Czaika and Vothknecht (2014), in relation to the household head and their own low migration aspirations. While this study does not specifically include factors capturing community and family norms, the results resemble those of De Jong (2000) and Gubhaju and De Jong (2009), in which family pressure and social norms directly influence migration intentions.

Representing the household as one homogenous unit is a limitation of this study. Due to the data collection method, various household views and intra-household relationships were not accounted for. The amount of missing data and subsequent reduced sample size is an additional limitation; thus weakening the validity and generalizability of results. Education and labor migration may be determined by distinct indicators, thus the inability to separate labor and education migration aspirations limits the accuracy of predicting factors. Moreover, this study heavily relies on educational aspects of youth migration aspirations, yet labor migration still dominates the flow of migration in Georgia and Moldova (Danzer \& Dietz, 2014). The strength of this study is two-fold. First, the data are unique for both Georgia and Moldova, as the data includes household and individual information and that this study is derived from nationally representative samples. Secondly, this study is one of few that use a quantitative approach in investigating youth migration decision-making specifically.

\section{Conclusion}

This study has shown that individual capabilities, youth life aspirations and household capabilities significantly predict youth migration decision-making, whereas household aspirations do not. Both the individual's and household head's pride in the country showed the largest impacts on youth migration decision-making, followed by the financial worry of the household. Lastly, this study further emphasized the stark differences between youth male and female migration decision- 
making, showing that females are much more likely to be influenced by household factors compared to male counterparts.

Implications. Based on the present results, practical and theoretical implications are derived for the Georgian and Moldovan case. Given that youth's pride in the country signifies the chief impact on youth migration aspirations, government offices concerned with youth emigration should consider policies and programming that reassure residential satisfaction and integrate youth in policy development. Youth programs focused on skill development could bridge the gap between educational institutions and the labor market, thus reduce the rate of over qualified and underemployed youth in Georgia and Moldova. The broader theoretical implications from this study lie in reiterating how, in the Georgian and Moldovan context, economic and gender inequalities can influence youth migration aspirations.

Future-research. This study shows evidence that youth may have similar decision-making mechanisms as adults, yet factors such as transitions to adulthood or 'waithood'(De Jong \& Graefe, 2008; Heckert, 2015; Horváth, 2008), role models (Beaman, Duflo, Pande, \& Topalova, 2012), cultural exchange, media and social networks (Archer, DeWitt, \& Wong, 2014) should not be neglected. Therefore researchers must question how youth migration decision-making is unique from adults. Additionally, education and labor migration for youth should be investigated separately as predictors may vary, especially among male and female samples. Measuring aspirations as an index is worth exploring to advance statistical prowess in predicting migration aspirations. Lastly, accounting for intra-household relationships is vital to fully capture social and gender norms along with how household members (differently) influence youth migration aspirations.

\section{References}

Archer, L., DeWitt, J., \& Wong, B. (2014). Spheres of influence: what shapes young people's aspirations at age 12/13 and what are the implications for education policy? Journal of Education Policy, 29(1), 58-85. https://doi.org/10.1080/02680939.2013.790079

Badurashvili, I., \& Nadareishvili, M. (2012). Social Impact of Emigration and Rural-Urban Migration in Central and Eastern Europe Final Country Report Georgia. Gesellschaft für Versicherungswissenschaft und -gestaltung e.V.(GVG).

Bandura, A. (1994). Self-Efficacy. In Encyclopedia of human behavior (Vol. 4, pp. 71-81). Academic Press.

Beaman, L., Duflo, E., Pande, R., \& Topalova, P. (2012). Female leadership raises aspirations and educational attainment for girls: a policy experiment in India. Science, 335(6068), 582-586. https://doi.org/10.1126/ science. 1212382

Bernard, T., \& Seyoum Taffesse, A. (2014). Aspirations: An Approach to Measurement with Validation Using Ethiopian Data. Journal of African Economies, 23(2), 189-224. https://doi.org/10.1093/jae/ejt030

Bjarnason, T. (2014). Adolescent Migration Intentions and Population Change: A 20-Year Follow-Up of Icelandic Communities. Sociologia Ruralis, 54(4), 500-515. https://doi.org/10.1111/soru.12050

Carling, J. (2002). Migration in the age of involuntary immobility: Theoretical reflections and Cape Verdean experiences. Journal of Ethnic and Migration Studies, 28(1), 5-42. https://doi.org/10.1080/ 13691830120103912

Carling, J., \& Schewel, K. (2017). Revisiting aspiration and ability in international migration. Journal of Ethnic and Migration Studies. https://doi.org/10.1080/1369183X.2017.1384146

Carling, J., \& Talleraas, C. (2016). Root causes and drivers of migration. Oslo: Peace Research Institute Oslo (PRIO).

Cohen, J. H., Rodriguez, L., \& Fox, M. (2008). Gender and migration in the Central valleys of Oaxaca. International Migration, 46(1), 79-101. https://doi.org/10.1111/j.1468-2435.2008.00437.x 


\section{Youth Migration Aspirations in Georgia and Moldova}

Cohen, J., \& Sirkeci, I. (2011). Cultures of Migration: The Global Nature of Contemporary Mobility (1st ed.). Austin: University of Texas Press.

Czaika, M., \& Vothknecht, M. (2012). Migration as cause and consequence of aspirations (IMI Working Paper Series 2012 No. 57). IMI Working Paper Series. Oxford.

Czaika, M., \& Vothknecht, M. (2014). Migration and aspirations - are migrants trapped on a hedonic treadmill? IZA Journal of Migration, 3(1), 1. https://doi.org/10.1186/2193-9039-3-1

Danzer, A. M., \& Dietz, B. (2014). Labour Migration from Eastern Europe and the EU's Quest for Talents. Journal of Common Market Studies, 52(2), 183-199. https://doi.org/10.1111/jcms.12087

DaVanzo, J. (1981). Microeconomic Approaches to Studying Migration Decisons. In G. De Jong \& R. W. Gardner (Eds.), Migration Decision Making: Multidisciplinary Approaches to Microlevel Studies in Developed and Developing Countries (1st ed., pp. 90-129). New York: Pergamon Press.

de Haas, H. (2014). Migration Theory: Quo Vadis? (24 No. 100). IMI Working Papers Series. Oxford.

De Jong, G. F. (2000). Expectations, gender, and norms in migration decision-making. Population Studies, 54(3), 307-319. https://doi.org/10.1080/713779089

De Jong, G. F., \& Fawcett, J. T. (1981). Motivations for Migration: An Assessment and a Value-Expectancy Research Model. In G. De Jong \& R. W. Gardner (Eds.), Migration Decision Making: Multidisciplinary Approaches to Microlevel Studies in Developed and Developing Countries (1st ed., pp. 13-58). https://doi.org/10.1016/B978-0-08-026305-2.50008-5

De Jong, G. F., \& Graefe, D. R. (2008). Immigrant redistribution and life course trigger events: Evidence from US interstate migration. Migration Letters, 5(2): 123-134. DOI: https://doi.org/10.33182/ml.v5i2.48

De Jong, G. F., Root, B., Gardner, R., Fawcett, J., \& Abad, R. (1986). Migration intentions and behavior: Decision making in a rural Philippine province. Population and Environment, 8(1-2), 41-62. https://doi.org/10.1007/BF01263016

Gardner, R. (1981). Macrolevel Influences on the Migration Decision Process. In G. De Jong \& R. W. Gardner (Eds.), Migration Decision Making: Multidisciplinary Approaches to Microlevel Studies in Developed and Developing Countries (1st ed., pp. 59-89). New York: Pergamon Press.

Gubhaju, B., \& De Jong, G. F. (2009). Individual versus household migration decision rules: Gender and marital status differences in intentions to migrate in South Africa. International Migration, 47(1), 31-61. https://doi.org/10.1111/j.1468-2435.2008.00496.x

Haug, S. (2008). Migration Networks and Migration Decision-Making. Journal of Ethnic and Migration Studies, 34(4), 585-605. https://doi.org/10.1080/13691830801961605

Heckert, J. (2015). New perspective on youth migration: Motives and family investment patterns. Demographic Research, 33, 765-800. https://doi.org/10.4054/DemRes.2015.33.27

Hofmann, E. T., \& Buckley, C. J. (2012). Cultural responses to changing gender patterns of migration in Georgia. International Migration, 50(5), 77-94. https://doi.org/10.1111/j.1468-2435.2010.00681.x

Horváth, I. (2008). The Culture of Migration of Rural Romanian Youth. Journal of Ethnic and Migration Studies, 34(5), 771-786. https://doi.org/10.1080/13691830802106036

Iversen, V. (2002). Autonomy in Child Labor Migrants. World Development, 30(5), 817-834. https://doi.org/10.1016/S0305-750X(02)00007-4

Iversen, V. (2003). Intra-Household Inequality: A challenge for the capability approach? Feminist Economics, 9(2-3), 93-115. https://doi.org/10.1080/1354570032000080868

Kahanec, M., \& Fabo, B. (2013). Migration strategies of crisis-stricken youth in an enlarged European Union. Transfer: European Review of Labour and Research, 19(3), 365-380. https://doi.org/10.1177/ 1024258913493701

Kao, G. (2004). Parental Influences on the Educational Outcomes of Immigrant Youth. International Migration Review, 38(2), 427-449.

Lauby, J., \& Stark, O. (1988). Individual Migration as a Family Strategy: Young Women in the Philippines. Population Studies, 42(3), 473-486. Retrieved from https://www.tandfonline.com/doi/pdf/10.1080/ 0032472031000143596 ?needAccess $=$ true

Loschmann, C., \& Siegel, M. (2013). The Influence of Vulnerability on Migration Intentions in Afghanistan (UNU-MERIT working paper series No. 2013-038).Maastricht. 
Massey, D. S. (1990). Social Structure, Household Strategies, and the Cumulative Causation of Migration. Population Index, 56(1), 3-26. Retrieved from http://www.jstor.org/stable/3644186

Massey, D. S., Arango, J., Hugo, G., Kouaouci, A., Pellegrino, A., \& Taylor, J. E. (2009). Worlds in Motion: Understanding International Migration at the End of the Millennium. Oxford: Clarendon Press.

National Council of Youth Organizations of Georgia. (2009). National Report on Georgian Youth. Tbilsi.

Pinger, P. (2010). Come back or stay? Spend here or there? Return and remittances: The case of Moldova. International Migration, 48(5), 142-173. https://doi.org/10.1111/j.1468-2435.2009.00562.x

Punch, S. (2002). Youth transitions and interdependent adult-child relations in rural Bolivia. Journal of Rural Studies, 18(2), 123-133. https://doi.org/10.1016/S0743-0167(01)00034-1

Rotter, J. (1966). Generalized expectancies for internal versus external control of reinforcement. Psychological Monographs: General and Applied, 80(1), 1-28.

Sirkeci, I., \& Cohen, J. H. (2016). Cultures of Migration and Conflict in Contemporary Human Mobility in Turkey. European Review, 24(3), 381-396. https://doi.org/10.1017/S1062798716000119

Stark, O., \& Bloom, D. (1985). The New Economics of Labor Migration. AEA, 75(2), 173-178.

Stock, J. H., \& Watson, M. M. (2012). Introduction to Econometrics (3rd ed.). Edinburgh Gate: Pearson Education Limited.

van Dalen, H. P., \& Henkens, K. (2008). Emigration Intentions: mere words or true plans? Explaining international migration intentions and behavior (No. 200-60). Tilburg.

Vanhee, J., Hämäläinen, A.-M., Brandtner, G.-M., Titarenko, L., \& Williamson, H. (2009). Youth Policy in Moldova An International Review. Strasbourg.

Vanore, M. (2015). Family-Member Migration and the Psychosocial Health Outcomes of Children in Moldova and Georgia. Maastricht University, Maastricht.

Vanore, M., \& Siegel, M. (2015). The evolution of gendered migration trajectories from Moldova and Georgia. Comparative Migration Studies, 3(4), 1-21. https://doi.org/10.1007/s40878-015-0001-z

Vladicescu, N., \& Vremis, M. (2012). Social Impact of Emigration and Rural-Urban Migration in Central and Eastern Europe Final Country Report Moldova. Gesellschaft für Versicherungswissenschaft und gestalung e.V. (GVG).

Whitehead, A., Hashim, I. M., \& Iversen, V. (2007). Child Migration, Child Agency and Inter-generational Relations in Africa and South Asia (working paper No. T24). Sussex. Retrieved from http://www.migrationdrc.org

World Bank. (2017a). Unemployment, total (\% of total labor force) (national estimate) | Data. Retrieved July 12, 2018, from https://data.worldbank.org/indicator/SL.UEM.TOTL.NE.ZS?locations=MD-GE

World Bank. (2017b). Unemployment, youth total (\% of total labor force ages 15-24) (national estimate) | Data. Retrieved July 12, 2018, from https://data.worldbank.org/indicator/ SL.UEM.1524.NE. ZS?locations=MD-GE. 


\section{Youth Migration Aspirations in Georgia and Moldova}

\section{Appendix A.}

Overview and descriptive statistics of variables

\begin{tabular}{|c|c|c|}
\hline Variable & Description & Mean (SD) \\
\hline Age & Age (in years) & $15.23(2.57)$ \\
\hline Gender & Gender $(1=$ Male, $0=$ female $)$ & $.52(.49)$ \\
\hline Enrollment ${ }^{\mathrm{c}}$ & $\begin{array}{l}\text { If those between ages } 16 \& 19 \text { are currently enrolled in an } \\
\text { educational institution }(0=\text { no, } 1=\text { yes, } 2=\text { not applicable })\end{array}$ & $\begin{array}{l}0=5.46 \% \\
1=30.55 \% \\
2=63.99 \%\end{array}$ \\
\hline $\begin{array}{l}\text { Youth Pride in } \\
\text { Country }\end{array}$ & $\begin{array}{l}\text { How proud are you to be Georgian/Moldovan? }(1=\text { very } \\
\text { proud; } 2=\text { quite proud; } 3=\text { not very proud; } 4=\text { not at all proud; } \\
5=\mathrm{I} \text { am not Georgian/Moldovan })\end{array}$ & $\begin{array}{l}1=60.27 \%^{2} \\
2=29.57 \% \\
3=8.11 \% \\
4=0.38 \% \\
5=1.67 \%\end{array}$ \\
\hline Ethnicity & $\begin{array}{l}\text { Which ethnic group do you consider yourself to be part of? } \\
\text { Condensed to }\left(0=\text { Georgian/Moldovan, } 1=\text { Russian or } \text { CIS }^{1} \text {, }\right. \\
2=\text { other }) \text { Directed to youth }\end{array}$ & $\begin{array}{l}0=87.7 \%{ }^{2} \\
1=5.9 \% \\
2=6.4 \%\end{array}$ \\
\hline
\end{tabular}

Network

Dependency in

Decision Making

Education

Expectations
Are you a member of any groups or clubs in your local area or at school? $(1=$ yes, $0=$ no $)$

Other people in my family make all the decisions about how I spend my time $(1=$ not true, $2=$ somewhat true, $3=$ certainly true)

Considering your family's current situation, how likely is it that you will complete this level of education (you desire to achieve $) ?(0=$ impossible, $10=$ certain $)$
Education

Aspirations

Responsibility vs

Destiny

Hard-work vs Luck

$\begin{array}{ll}\text { Country } & \begin{array}{l}1=\text { To be successful, above all one needs to work very hard, } \\ 0=\text { To be successful, above all one needs to be lucky }\end{array} \\ \text { Urban }^{\mathrm{c}} & \begin{array}{l}\text { Original dataset }(0=\text { Georgia, } 1=\text { Moldova }) \\ \text { Area of household }(1=\text { urban, } 0=\text { rural) }\end{array} \\ \text { Household size } & \begin{array}{l}\text { How many people-including yourself, your children and all } \\ \text { people currently not present- do you consider part of the } \\ \text { household? (number of people) }\end{array} \\ & \begin{array}{l}\text { Where would you put your satisfaction with your life as a } \\ \text { whole }(1=\text { very unsatisfied, } 10=\text { very satisfied) Directed to the } \\ \text { head of the household }\end{array}\end{array}$

Imagine you had no constraints and could study for as long as you liked, or go back to school if you already left. What is the highest level of formal education you WISH to complete? ( $2=$ lower secondary or less, $3=$ upper secondary, 4=postsecondary, $5=$ bachelor, $6=$ master and $7=$ doctoral) $*$

Which of the two propositions do you most agree with?: $1=$ Each person is responsible for his/her success or failure in life, $0=$ One's success or failure in life is a matter of his/her destiny

Which of the two propositions do you most agree with?:

$1=$ To be successful, above all one needs to work very hard, head of the household
$1=31.61 \%{ }^{2}$

$2=43.90 \%$

$3=24.49 \%$

7.31(2.36)
$.81(.38)$

$2=2.37 \%^{2}$

$3=6.07 \%$

$4=19.79 \%$

$5=38.89 \%$

$6=25.02 \%$

$7=7.88 \%$

$.80(.39)$

$.55(.49)$

$.30(.46)$

4.84(1.58)

$6.13(2.23)$ 


$\begin{array}{ll}\text { Living Conditions } & \begin{array}{l}\text { How would you evaluate the present living conditions of } \\ \text { your household? }(1=\text { very good, } 2=\text { good, } 3=\text { neither good nor } \\ \text { bad, 4=bad, 5=very bad })\end{array} \\ \begin{array}{l}\text { Household head } \\ \text { Pride in Country }\end{array} & \begin{array}{l}\text { How proud are you to be Georgian/Moldovan? (1=very } \\ \text { proud; } 2=\text { quite proud; } 3=\text { not very proud; } 4=\text { not at all proud; } \\ 5=\mathrm{I} \text { am not Georgian/Moldovan) }\end{array} \\ \text { Household } & \begin{array}{l}\text { What is the highest degree of school [name] received? } \\ \text { Education Level }\end{array} \\ \begin{array}{l}\text { Maximized for household }(3=\text { lower secondary or less, } \\ \text { 7=upper secondary,5=post-secondary, } 6=\text { incomplete tertiary, } \\ 7=\text { bachelors, } 8=\text { master or higher)* }\end{array}\end{array}$

(20)

Financial Worries In the last 12 months, how often did/do you worry that your total household income will not be enough to meet your household's expenses and bills? ( $1=$ every day, $2=$ more than 3 times a week, $3=$ at least once a week, $4=$ at least once a month, $5=$ less often or never)

Migrant Count ${ }^{\mathrm{c}}$

Derived from: Has [name] ever lived abroad for three or more months at once time since 1999? (1= yes, $2=$ no)Number of migrants within the household. $(0,1,2,3=3$ or more)

Dependency Ratio ${ }^{c} \quad$ Number of dependent (14 and younger plus 65 and older) divided by working persons (15-64 years)(in percent)

\section{$3.13(.82)$}

$1=50.49 \%{ }^{2}$

$2=31.61 \%$

$3=12.69 \%$

$4=2.43 \%$

$5=2.50 \%$

$3=13.27 \%^{2}$

$4=7.66 \%$

$5=34.57 \%$

$6=16 \%$

$7=18.88 \%$

$8=9.63 \%$

$1=67.17 \%{ }^{2}$

$2=13.27 \%$

$3=8.72 \%$

$4=7.81 \%$

$5=3.03 \%$

$.66(.91)$

$51.30(55.23)$

\begin{tabular}{|c|c|c|}
\hline $\begin{array}{l}\text { Education } \\
\text { Aspirations for } \\
\text { Youth }\end{array}$ & $\begin{array}{l}\text { Imagine finances were not a problem and everything else } \\
\text { went right, what is the highest level of formal education you } \\
\text { WISH [child] could complete? }(2=\text { lower secondary or lower, } \\
3=\text { upper secondary, } 4=\text { post-secondary, } 5=\text { bachelors, } \\
6=\text { =masters, } 7=\text { doctorate)* }\end{array}$ & $\begin{array}{l}2=2.27 \%^{2} \\
3=4.25 \% \\
4=18.35 \% \\
5=37.83 \% \\
6=24.94 \% \\
7=12.36 \%\end{array}$ \\
\hline $\begin{array}{l}\text { Parent encourages } \\
\text { Independent } \\
\text { Thinking }\end{array}$ & $\begin{array}{l}\text { When your [caregiver] wants you to do something, does } \\
\text { [caregiver] encourage you to think independently? (1=yes, } \\
0=\text { no) }\end{array}$ & $.94(.22)$ \\
\hline $\begin{array}{l}\text { Parent encourages } \\
\text { Hard-Work }\end{array}$ & $\begin{array}{l}\text { When you are not doing well in school, he/she encourages } \\
\text { you to work harder? }(1=\text { yes, } 0=\text { no })\end{array}$ & $.96(.18)$ \\
\hline $\begin{array}{l}\text { Expect Financial } \\
\text { Support from } \\
\text { Youth }\end{array}$ & $\begin{array}{l}\text { Do you think [child] will give you financial support in the } \\
\text { future }(1=\text { yes, } 0=\text { no) }\end{array}$ & $.37(.48)$ \\
\hline
\end{tabular}




\section{Appendix B.}

Table: Full Model Average Marginal Effects

\begin{tabular}{|c|c|c|}
\hline & Male & Female \\
\hline Age & $0.02 *(0.01)$ & $0.02 *(0.01)$ \\
\hline Enrollment & $0.03(0.04)$ & $0.01(0.05)$ \\
\hline \multicolumn{3}{|c|}{ Youth's Pride in the Country (ref. Very Proud) } \\
\hline Proud & $0.13^{* * *}(0.05)$ & $0.16^{* * *}(0.04)$ \\
\hline Not Very Proud & $0.19 * *(0.07)$ & $0.16^{* *}(0.07)$ \\
\hline Not at all Proud & $0.25(0.24)$ & \\
\hline Not Georgian/Moldovan & $-0.21(0.15)$ & $-0.10(0.20)$ \\
\hline \multicolumn{3}{|c|}{ Ethnicity (ref. Georgian/Moldovan) } \\
\hline Russian \& CIS & $-0.02(0.11)$ & $0.00(0.10)$ \\
\hline Other & $-0.09(0.06)$ & $-0.09(0.06)$ \\
\hline Network & $0.11 * *(0.04)$ & $0.06(0.04)$ \\
\hline \multicolumn{3}{|c|}{ Dependency in Decision-Making (ref. Not True) } \\
\hline Somewhat True & $-0.08 * *(0.04)$ & $-0.13 * * *(0.04)$ \\
\hline Certainly True & $-0.02(0.05)$ & $-0.09 *(0.05)$ \\
\hline Education Expectation & $0.01(0.00)$ & $-0.00(0.00)$ \\
\hline \multicolumn{3}{|c|}{ Educational Aspirations (ref. Lower Secondary) } \\
\hline Upper Secondary & $0.09(0.11)$ & $-0.10(0.20)$ \\
\hline Post-Secondary & $0.07(0.09)$ & $0.02(0.19)$ \\
\hline Bachelor & $0.11(0.10)$ & $-0.04(0.19)$ \\
\hline Master & $0.05(0.11)$ & $-0.05(0.20)$ \\
\hline Doctoral & $0.36^{* * *}(0.14)$ & $0.13(0.21)$ \\
\hline Responsibility vs Destiny & $-0.03(0.05)$ & $-0.19 * * *(0.04)$ \\
\hline Hard Work vs Luck & $-0.00(0.04)$ & $0.11 * *(0.05)$ \\
\hline Country (ref. Georgia) & $-0.07(0.06)$ & $-0.03(0.06)$ \\
\hline Urban (ref. Rural) & $-0.03(0.05)$ & $0.05(0.04)$ \\
\hline HH Size & $-0.00(0.01)$ & $-0.00(0.01)$ \\
\hline HH Life Satisfaction & $0.01(0.00)$ & $0.01 * *(0.00)$ \\
\hline HH Living Conditions & $0.02(0.02)$ & $0.04 *(0.02)$ \\
\hline \multicolumn{3}{|c|}{ HH Pride in the Country (ref. Very Proud) } \\
\hline Proud & $0.11 * *(0.05)$ & $0.05(0.05)$ \\
\hline Not Very Proud & $0.19 * * *(0.07)$ & $0.09(0.06)$ \\
\hline Not at all Proud & $0.37 * * *(0.14)$ & $0.16(0.11)$ \\
\hline Not Georgian/Moldovan & $0.21(0.20)$ & $0.21(0.22)$ \\
\hline HH Education Level & $0.00(0.01)$ & $-0.02 *(0.01)$ \\
\hline Dependency Ratio & $0.00(0.00)$ & $0.00(0.00)$ \\
\hline \multicolumn{3}{|c|}{ Financial Worry (ref. Every Day) } \\
\hline 3 Times a Week & $-0.12 * *(0.05)$ & $0.12 * *(0.05)$ \\
\hline Once a Week & $-0.01(0.06)$ & $0.04(0.07)$ \\
\hline Once a Month & $-0.08(0.06)$ & $0.07(0.07)$ \\
\hline Less Often or Never & $0.08(0.10)$ & $0.43 * * *(0.10)$ \\
\hline HH Migrant Count & $0.02(0.02)$ & $0.02(0.02)$ \\
\hline
\end{tabular}




\begin{tabular}{lcc}
$\begin{array}{l}\text { Educational Aspirations for } \\
\text { Youth }\end{array}$ & $-0.02(0.02)$ & $0.03(0.02)$ \\
$\begin{array}{l}\text { Parent encourages } \\
\text { Independent Thinking }\end{array}$ & $0.08(0.09)$ & $0.04(0.08)$ \\
$\begin{array}{l}\text { Parent encourages Hard } \\
\text { Work }\end{array}$ & $0.20(0.13)$ & $0.07(0.10)$ \\
$\begin{array}{l}\text { Expect Financial Support } \\
\text { from Youth }\end{array}$ & $0.03(0.11)$ & $0.15(0.10)$ \\
$\begin{array}{l}\text { Pseudo R-Squared } \\
\text { Observations }\end{array}$ & 0.111 & 0.133 \\
\hline Note: Standard errors in parentheses, $* * * \mathrm{p}<0.01, * * \mathrm{p}<0.05, * \mathrm{p}<0.1$
\end{tabular}


122 Youth Migration Aspirations in Georgia and Moldova 